\title{
PERCEPCÃO SOBRE AS ESTRATÉGIAS DE RESPOSTA E ADAPTAÇÃO AOS RISCOS AMBIENTAIS: ESTUDO APLICADO EM PINHAIS, PARANÁ SOB A ÓTICA DAS INUNDAÇÕES
}

\author{
Murilo Noli da Fonseca \\ Pontifícia Universidade Católica do Paraná (PUCPR) \\ Programa de Pós-Graduação em Gestão Urbana \\ murilonoli@gmail.com \\ Larissa Maria da Silva Ferentz \\ Pontifícia Universidade Católica do Paraná (PUCPR) \\ Programa de Pós-Graduação em Gestão Urbana \\ ferentzengenharia@gmail.com
}

\begin{abstract}
RESUMO
Em uma conjuntura de intensas inquietudes e ambiguidades relacionadas às "mudanças climáticas", evidencia-se como essencial os estudos sobre a percepção aos riscos ambientais e as vulnerabilidades como base para a tomada de decisões que possibilitem reduzi-los e desenvolver estratégias sobre adaptação. Com o objetivo de avaliar sua percepção perante as estratégias de resposta e adaptação aos riscos ambientais, foi realizado um estudo de caso em um Conjunto Habitacional destinada às pessoas reassentadas de áreas de risco do município de Pinhais no Paraná: "Moradias Bonilauri". Ao todo foram aplicadas oito entrevistas com moradores. Dentre as principais medidas de adaptação dos entrevistados estão a construção de muretas e elevação do nível das casas; já o poder público investiu em drenagem, desassoreamento parque lineares. Este trabalho aponta que a redução do risco passa por ações voltadas à educação ambiental e à sensibilização dos moradores, a fim de envolver as pessoas com base na sua informação sobre os problemas socioambientais.
\end{abstract}

Palavras-chave: Resiliência. Riscos e Desastres. Gestão Municipal.

\section{PERCEPTION ON RESPONSE STRATEGIES AND ADAPTATION TO ENVIRONMENTAL RISKS: A STUDY APPLIED IN PINHAIS, PARANÁ FROM THE POINT OF FLOODING}

\begin{abstract}
In a context of intense concerns and ambiguities related to "climate change", studies on the perception of environmental risks and vulnerabilities are shown as essential as a basis for decision-making that makes it possible to reduce them and develop strategies on adaptation. In order to assess their perception of response strategies and adaptation to environmental risks, a case study was carried out in a Housing Complex aimed at people resettled from risk areas in the municipality of Pinhais in Paraná: "Moradias Bonilauri". In all, eight interviews were conducted with residents. Among the interviewees' main adaptation measures are the construction of small walls and raising the level of houses; the government has already invested in drainage, silencing of linear parks. This work points out that the risk reduction involves actions aimed at environmental education and the sensitization of residents, in order to involve people based on their information on socioenvironmental problems.
\end{abstract}

Keywords: Resilience. Risk and Disasters. Municipal Management.

\section{INTRODUÇÃO}

O processo de urbanização das cidades resulta em diversos problemas a serem enfrentados pelos gestores urbanos. No Brasil, a urbanização acelerada e sem planejamento adequado apresenta seus maiores impactos em bairros e comunidades precárias, com o assentamento de famílias em áreas de risco (como a proximidade de rios e encostas) e a degradação de áreas de proteção ambiental. Esse cenário, que concilia a vulnerabilidade social com as mudanças climáticas, resulta no aumento dos riscos a que as populações estão submetidas.

v. 22, n. $83 \quad$ out./2021

p. $01-18$

Página 1 
As mudanças climáticas tem sido associadas em todo o mundo como uma das principais causas da ocorrência de eventos extremos e seus impactos negativos. Diversos agentes e organizações promovem estudos sobre as consequências globais do desmatamento, das desigualdades sociais e do aumento da temperatura média do planeta. O fortalecimento dessas questões iniciou em $1988 \mathrm{com}$ a criação do Painel Intergovernamental sobre Mudanças Climáticas (IPCC), oriundo da resolução 43/53, da Organizações das Nações Unidas (ONU) (BACCHIEGGA, 2017).

A formação do IPCC amplificou a mundialização dos debates sobre as mudanças climáticas, dando mais visibilidade para as ações humanas que trazem graves consequências para o meio ambiente, tendo em vista que suas consequências são em escala mundial. Não obstante, também surgiu a oportunidade de analisar os processos de desenvolvimento adotados até então, a fim de buscar por medidas de mitigação dos impactos, e consequentemente, da redução dos riscos. "De temática praticamente irrelevante há décadas atrás, citada raramente dentro de poucos laboratórios no planeta, as mudanças climáticas hoje se apresentam como um tema global e de risco mundializado, constantemente debatido nas mais variadas esferas da sociedade" (BACCHIEGGA, 2017, p. 41).

Destaca-se que, os eventos extremos provenientes das mudanças climáticas, não possuem uma definição universal, já que o mesmo influencia diferentes campos disciplinares. $O 5^{\circ}$ Relatório de Avaliação do Painel Intergovernamental de Mudanças Climáticas corrobora tal afirmação ao declarar que "não há uma definição consistente na literatura científica do que constitui um evento climático extremo, e isso complica avaliações globais comparativas" (IPCC, 2013, p. 64). Dessa forma, esses eventos recebem distintas terminologias. São denominados de severos, raros, de alto impacto (STEPHENSON, 2008), excepcionais ou extremos (IPCC, 2013), ou anomalias climáticas (PEREIRA et al, 2002). Tais eventos são "episódios cuja manifestação pontual no tempo e no espaço caracteriza-se por apresentar magnitude bastante distante do padrão normal ou habitual do clima de uma data localidade" (MENDONÇA \& ROSEGHINI, 2012, p. 211).

Os eventos extremos exibem alta dinamicidade e são gerados por uma ruptura na variabilidade natural do ritmo. Ou seja, um evento extremo para ser considerado como tal deve exibir: baixa periodicidade, intensidade anômala ou dimensão e gravidade dos impactos e implicações que exercem sobre a sociedade (BENISTON \& STEPHENSON, 2004). Os impactos negativos de um evento extremo sobre a sociedade assinalam um desastre. Isso não é novo, uma vez que acontece desde a constituição das primeiras aglomerações humanas até a concepção contemporânea das cidades (MONTEIRO, 1991).

Deve-se salientar a diferença entre os conceitos de desastre e catástrofe. O primeiro resulta da ação de eventos perigosos que ocorrem em determinada área geográfica, nomeadamente com condições sociais vulneráveis (como resultado de consequências cumulativas de decisões - sejam elas individuais e/ou coletivas - previamente adotadas, ligadas à organização e ao planejamento do território), durante um período de tempo curto, culminando na destruição da morfologia de uma comunidade e sobrepujando a resiliência de tal. As catástrofes, no que lhe concerne, expõem predicados idênticos ao desastre. Contudo, a distinção entre ambos reside na escala ou na magnitude dos impactos e, por isso, a catástrofe detém dimensões mais profusas, demandando elevados gastos de dinheiro e de tempo para que aconteça o restabelecimento (BOTKIN \& KELLER, 2011).

Deste modo, a construção social do risco depende tanto da magnitude dos eventos quanto da importância que a sociedade atribui aos mesmos. De um lado, as cidades e tecnologias permitem a conexão de culturas e lugares que não eram possíveis para muitos, e de outro, ela tem sido responsável pela aproximação do risco nas comunidades. A partir do momento em que situações de vulnerabilidade e ameaças naturais ou tecnológicas ocorrem, os impactos são compartilhados mundialmente, atentando a população para os problemas e perigos a que estão sujeitas (BACCHIEGGA, 2017). Dentre os principais problemas identificados nas cidades, é possível citar: falta de planejamento e infraestrutura, padrões ineficientes de uso e ocupação do solo, despreparação de gestores e da própria população, desigualdades pela má distribuição de riquezas, dentre outros (SULAIMAN; ALEDO, 2016).

Uma forma de auxiliar a gestão local nesse processo, é integrar a percepção da população no seu planejamento. Por meio de pesquisas qualitativas complementares aos indicadores censitários existentes, é possível identificar, não só, os principais problemas que cercam os diferentes bairros das cidades, como também, utilizar as ideias dos próprios moradores para solucionar estas questões. Deste modo, a percepção se torna um importante instrumento de desenvolvimento urbano mais sustentável (FERENTZ; GARCIAS; SETIM, 2020).

No Brasil, as pesquisas realizadas até o momento sobre a percepção de riscos ambientais têm proporcionado resultados extraordinariamente elucidativos no que diz respeito à relação dos indivíduos

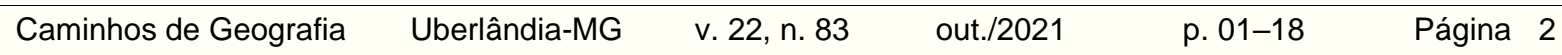


com os riscos no meio em que vivem. Destaca-se que estes riscos se apresentam das formas mais distintas, como estudos sobre a vulnerabilidade populacional para risco tecnológico ambiental proximidade das pessoas com áreas industriais, de disposição de resíduos ou depósitos de combustível (OLIVEIRA; BORGES, 2018); sobre a exposição frente atividades de trabalho - como mineração (DUTRA; NAVONI; AMARAL, 2019) e agrotóxicos (NORDER; LOBO, 2019), e também, quanto aos desastres naturais (RIBEIRO; VIEIRA; TÔMIO, 2017). Observa-se que, essas pesquisas contribuem e servem como base para a concepção de estratégias e políticas centradas na prevenção e na redução do risco de desastres. Por essa razão, promover uma intervenção na relação entre o ser humano e o ambiente demanda a incorporação da percepção dos indivíduos na tomada de decisão.

De modo a preencher esta lacuna, de uma análise geográfica que permeie a compreensão das condições de vulnerabilidade socioambiental e dos fenômenos, esta pesquisa busca analisar as estratégias de resposta e de adaptação em uma das áreas mais críticas e vulneráveis socioambientalmente ao risco de inundações no município de Pinhais, estado do Paraná: um conjunto habitacional instituído pelo poder público e destinado às pessoas reassentadas de áreas de risco. Para atender esse objetivo, serão respondidas as seguintes questões problema: Quais são as medidas adotadas pelo poder público para tentar solucionar o problema das inundações no conjunto habitacional? Quais são as medidas adotadas por inciativa privada? As pessoas se sentem mais seguras após a implementação destas estratégias? Por essa razão, busca-se evidenciar as percepções de oito atores sociais do "Moradias Bonilauri".

Neste município, a problemática das inundações é uma realidade que ocorre antes mesmo de sua emancipação, em 1992. Estas áreas são caracterizadas pela condição geomorfológica desfavorável, como a baixa declividade dos terrenos, que se encontra ligada aos altos índices de urbanização nas planícies de inundação e do alto contingente populacional passível de ser atingido. Com isso, o poder público desenvolveu medidas para reduzir os impactos e os riscos, como a criação da Unidade Territorial de Planejamento, da barragem do Iraí, de parques lineares e o reassentamento de pessoas de áreas de risco para conjuntos habitacionais.

\section{REVISÃO DA LITERATURA}

Diversos estudos têm buscado compreender os riscos ambientais em distintos campos do conhecimento. Embora os pesquisadores e os técnicos apresentem consciência da importância de pesquisas que envolvam a interação ser humano-ambiente, aquelas que incorporam a percepção ainda são negligenciadas em função de outras perspectivas (KATES, 1978; WHYTE, 1985; SOUZA; ZANELLA, 2010). Estudos com a abordagem perceptiva ganham ênfase à medida que diversos organismos internacionais e nacionais, como a ONU e a Defesa Civil, assinalam que uma das estratégias para reduzir os riscos consiste em compreender como as pessoas os percebem e se procuram desenvolver medidas que reduzam a sua materialização e as consequências associadas a estas.

Por meio de estudos com abordagem perceptiva há o surgimento de uma conduta assinalando para alterações na compreensão do comportamento espacial dos indivíduos e realçando a compreensão cognitiva do ambiente na organização da mente. Isto ocorre por meio de uma relação direta, contínua e prolongada do sujeito com um território, onde se desenvolvem percepções que se transformam em subsídios essenciais na avaliação ambiental (MACHADO, 1998). Por isso, as pesquisas de percepção sobre os riscos ambientais têm se mostrado primordiais na compreensão das vulnerabilidades e dos riscos, especialmente para os geógrafos, embora existam poucos trabalhos desenvolvidos até o momento no Brasil (SOUZA; ZANELLA, 2010).

As primeiras pesquisas sobre percepção dos riscos ambientais surgiram na década de 1960. Uma das pioneiras nestes estudos foi Anne White, que se preocupou com as técnicas e as metodologias empregadas na percepção e desenvolveu múltiplos trabalhos, como é o diagnóstico do comportamento e percepção de sujeitos atingidos por inundações nos Estados Unidos. Já Kates procurou compreender como os moradores de áreas de risco a furacões e tempestades nos Estados Unidos percebiam esses fenômenos e se procuravam desenvolver medidas de redução ao risco. Tais estudos se mostraram extremamente reveladores e possibilitaram verificar a imagem que os indivíduos possuem sobre o ambiente em que vivem e as diferenças entre as medidas de redução ao risco pelas pessoas que residem em área de risco e os gestores públicos (CASTRO, 2000).

A expressão "percepção de riscos" pode ser compreendida como sendo o "processo pelo qual os riscos são subjetivos, ou intuitivamente, compreendidos e avaliados" (WHYTE, 1985, p.115). Em outras palavras, uma avaliação dos riscos ambientais perpassa necessariamente pela compreensão da associação entre o

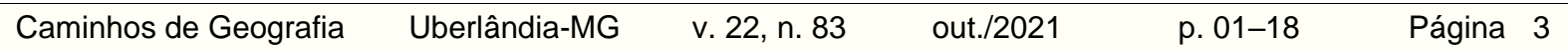


objetivo e o percebido (SOUZA; ZANELLA, 2010). Pompílio (1990) ratifica isso quando afirma que quanto mais homogêneo o grupo analisado for, em termos de característica socioculturais e escalas espaciais e temporais, maiores serão as percepções e reações em comum. "Esta constatação comprova a hipótese de que as percepções e reações diferenciadas dependem das características próprias do indivíduo, e que percepções e reações comuns estão na razão direta de suas experiências face ao convívio com os sucessivos eventos" (POMPÍLIO, 1990, p.233).

Baseado nisso, inúmeras pesquisas tem evidenciado que a percepção de riscos é influenciada pelos seguintes elementos: psicológicos e socioculturais (DOUGLAS, 1994; SLOVIC, 2000; RENN, 2008); aqueles atrelados ao local de ocorrência e à proximidade de riscos (VEYRET, 2007; BRODY et al., 2008; SANTOS; MARANDOLA JR., 2012); e o acesso às informações e a maneira como são expostos pelos meios de comunicação e por pesquisadores e gestores públicos (MOSER, 2006; DI GIULIO; FERREIRA, 2013). Ela pode ser influenciada por elementos da situação de risco, como a magnitude (força do evento), frequência (tempo médio de regresso de eventos extremos), duração (tempo de manifestação do fenômeno), área de alcance (extensão da área atingida), velocidade de deflagração (rapidez com que o evento ocorre), dispersão espacial (padrão espacial da ocorrência) e distribuição temporal (padrão temporal da distribuição) (BURTON; KATES; WHITE, 1993; SOUZA; ZANELLA, 2010). Já Whyte (1985) elenca os impactos e as consequências como fatores capazes de influenciar a percepção.

Deve-se compreender também a ação do poder público na redução do risco. Xavier (1996) mostra que há uma aproximação entre a percepção dos indivíduos que residem em áreas de risco e a percepção dos técnicos e dos gestores públicos sobre as medidas a serem adotadas nessa situação. Por outro lado, Whyte (1985) observou que no Vale do Nochixtlan, no sudoeste do México, os gestores públicos buscavam minimizar as consequências das voçorocas por meio de medidas estruturais, enquanto que os residentes se ressentiam pela degradação gerada por tais medidas sobre a lavoura. "Talvez o mais difícil de tudo, e que se encontra exatamente no centro da experiência da cidade, seja encontrar um modo objetivo de registrar o que os residentes pensam acerca do local onde vivem [...] uma vez que os locais não são apenas o que são, mas a percepção que temos deles" (LYNCH, 1999, p.331).

Nessa ocasião, a escolha pelo local de residência é fruto da concretização da percepção, ou seja, é uma prática suscitada por meio de um processo cognitivo (SOUZA; ZANELLA, 2010). No caso das habitações em áreas de risco, os prejuízos gerados por certos fenômenos podem ser suplantados pelos custos da habitação ou pela proximidade do trabalho (BURTON; KATES; WHITE, 1993). Por isso, os pesquisadores e os gestores públicos devem entender os motivos pelos quais determinados indivíduos permanecem em áreas de risco. Xavier (1996, p.171) corrobora tal afirmação ao destacar que "o fato de ser proprietário da residência e a vantagem da proximidade do centro da cidade ou do local de trabalho interfere na avaliação social do risco e, consequentemente, na decisão sobre continuar ou não vivendo em áreas de risco".

No município colombiano de Manizales, Chardon (1997) certifica que a população com fragilidade econômica tende a desconsiderar os riscos, pois possuem apreensões mais imediatas, como a alimentação. Reflexo disso é que apenas $28 \%$ da população ameaçada avalia seu bairro como uma área de risco, e mais de $75 \%$ das pessoas não elegeram os riscos como prioridades locais, considerando-se satisfeitos com a ocasião. Nesse sentido, a percepção dos indivíduos que vivem em áreas de risco varia entre aqueles que desconhecem as ameaças (VESTENA et al., 2014), os que aguardam a ação do poder público na redução ou gestão dos riscos (XAVIER, 1996), e aqueles que se submetem aos riscos por não ter outra opção de moradia (SANTOS; MARANDOLA JR., 2012). Por essa razão, garante-se que, perante uma situação de exclusão socioespacial, a exposição ao risco, comumente, deriva de uma escolha forçada e não voluntária (SOUZA; ZANELLA 2010).

No âmbito da avaliação dos riscos, os indivíduos possuem uma forte dependência da memória, que permite recordar os eventos que acontecem com regularidade, aqueles mais significativos ou os mais recentes (WHYTE, 1985). Os eventos que ocorrem com maior regularidade e que afetam diretamente a vida das pessoas são facilmente lembrados e, por isso, têm sua probabilidade melhor avaliada, em comparação àqueles mais pontuais. No entanto, várias pessoas avaliam como improváveis tais eventos ocorrerem mais de uma vez em um breve período de tempo. Também tendem a prever a sua ocorrência conforme uma revelação, uma intuição ou na extrapolação (experiência adquirida no decorrer da vida de uma pessoa) (KATES, 1978).

Pode-se observar que alguns indivíduos já implementaram medidas que buscassem reduzir o risco, em maior ou menor grau, como forma de continuar no lugar onde vivem. Tais medidas podem ser realizadas em duas esferas: a primeira é individual e ocorre na residência, onde cada indivíduo procura erradicar o problema; e a segunda é coletiva, no qual há o envolvimento da vizinhança, da comunidade. Mas essa

$\begin{array}{llllll}\text { Caminhos de Geografia } & \text { Uberlândia-MG } & \text { v. 22, n. } 83 & \text { out./2021 } & \text { p. 01-18 } & \text { Página } 4\end{array}$


última forma é menos recorrente, uma vez que se encontram sujeitas a deliberações que envolvem a comunidade e o poder público (KATES, 1978).

No entanto, destaca-se que, algumas medidas não são de alcance individual, cabendo ao poder público executá-las. Isso ocorre, principalmente, em áreas mais vulneráveis, não tendo ainda, garantias de que a adoção de medidas será efetiva, já que o próprio poder público apresenta dificuldades para implementálas (SOUZA; ZANELLA, 2010). É por isso que, muitas pessoas preferem tentar resolver os problemas por conta própria, mesmo que seja insuficiente (WHYTE, 1985). Normalmente, as pessoas que já apresentaram danos estimáveis no passado e acreditam em novos estragos são as que apresentam a maior motivação para adotar medidas. Caso haja uma diminuição na quantidade dos eventos e se eles ocorrerem de maneira ocasional há a probabilidade de as medidas serem atrofiadas com o tempo. Porém, em algumas situações, as medidas não são adotadas pelos residentes por serem avaliadas como dispensáveis. Isto é, certos grupos se sujeitam aos riscos ao não adotarem ou promoverem medidas impróprias (KATES, 1978). Em outros casos, a não adoção deriva de uma circunstância atribuída as suas condições de vida, especialmente no que tange as medidas mais caras.

Desta forma, a compreensão dos fatores que influenciam a percepção ao risco é fundamental, já que considera a vulnerabilidade e a adaptação mediante às ameaças e aos desastres ligados a eventos extremos. Tal abordagem procura inserir a experiência dos fenômenos como foco substancial, onde cada indivíduo possui uma visão ímpar dos lugares, fruto da sua interação com o ambiente. É no espaço que a experiência humana é formada, é onde os sentidos são assimilados. O lugar é um modo singular de ligar as experiências do espaço e se reflete em porções de apropriação do espaço vivido do indivíduo (DI GIULIO; FERREIRA, 2013).

Por isso, o lugar é composto por três elementos: percepção, experiência e valores. Ele resulta da transformação do espaço por meio da aquisição de definição e significado, isto é, o espaço ao abranger signos e simbolizações contrai identidade e passa a ser compreendido como lugar (TUAN, 1983). Conforme o lugar é vivido, as imagens são construídas a partir das experiências. Quando chegamos a um lugar e pedimos para uma pessoa representar um fenômeno, a representação de realidade será diferente. Isto porque os elementos inseridos serão os mais significativos para o autor da representação. Dessa maneira, é preciso conhecer a história e os fatos que estão por trás dos desenhos.

\section{METODOLOGIA}

Para a identificação, análise e caracterização da percepção ambiental dos atores sociais do Conjunto Habitacional "Moradias Bonilauri" será adotado a metodologia qualitativa, cuja característica é a compatibilidade com as particularidades humanas. Em outras palavras, a metodologia qualitativa tem como pressuposto a não redução dos fenômenos humanos às leis estáveis e inalteráveis da ciência (CHIZZOTTI, 2001), uma vez que incorpora em sua análise as significações que os indivíduos dão às suas ações e compreender outros elementos, tais como a questão familiar, social, econômica, cultural e política. Compreende-se aqui os atores sociais como sendo aqueles indivíduos ligados a órgãos públicos, organizações não governamentais (ONGs), agrupamentos sociais, indivíduos estratégicos na comunidade, ou seja, as pessoas que exercem algum tipo de liderança no círculo comunitário.

Procura-se também analisar por meio da fenomenologia a compreensão da experiência dos riscos de um lugar a partir da memória. Ou seja, o lugar é consequência de uma construção social que se repousa na memória e nas experiências vividas. O lugar só vai existir para alguém, para quem vive ou já viveu ou de alguma forma teve a oportunidade de experienciar um determinado espaço. Este conceito permite considerar os riscos e perigos na sua coesão, isto é, a sua dimensão fenomênica.

Assim, os riscos são determinados socialmente ao longo da história através da experiência coletiva, que permite a transmissão do conhecimento contraído de forma hereditária. Essa distribuição permite que sejam estabelecidas melhores condições e estratégias adequadas de adaptação, como maneira de responder as ameaças. Ou, do mesmo modo, atenuar os prejuízos do perigo com a diminuição das condições favoráveis. Nesse sentido, a memória e a experiência são elementos fundamentais para o estabelecimento de estratégias preventivas relacionadas ao risco do lugar.

O processo de reassentamento de 625 famílias que viviam em ocupações irregulares em Pinhais (Paraná) para o "Moradias Bonilauri" iniciou em 1998. Os autores realizaram entrevistas reflexivas com oito atores sociais do Conjunto Habitacional no segundo semestre de 2017, sendo quatro mulheres e quatro homens, na faixa etária entre 32 e 64 anos. Pois do mesmo modo que Aleksievich (2016) realça, é imprescindível ir

$\begin{array}{llllll}\text { Caminhos de Geografia } & \text { Uberlândia-MG } & \text { v. 22, n. } 83 & \text { out./2021 } & \text { p. 01-18 } & \text { Página } 5\end{array}$


para além da compreensão do evento em si. É preciso investigar o que acontece com o ser humano que vive em área de risco, como ele pensa, analisa, se comporta e reage diante dos fenômenos. E isso se faz mais necessário ainda quando, normalmente, não é oferecida a oportunidade de grande parcela da população que vive em situação de risco discorrer sobre as experiências e as estratégias de resposta adotadas perante as adversidades. Embora tal situação seja preconizada como essencial por diversos organismos e internacionais e nacionais, onde é garantido que os cidadãos que vivem em áreas de risco deveriam participar ativamente da identificação e avaliação de risco, sendo que toda a informação deve ser de livre acesso para toda a comunidade.

Destaca-se que a preocupação na concretização das entrevistas não foi orientada pela coleta de informações quantitativas, já que essa forma de coleta não poderia responder às questões estabelecidas pela presente pesquisa. Privilegiou-se informações qualitativas, e por isso foi selecionado um número menor de entrevistados, pois não caberia aqui tratá-los estatisticamente, uma vez que a riqueza dos pormenores contido nas conversas é fundamental para apreender elementos elucidativos das demandas ligadas à vivência e a experiência dos atores sociais com as inundações.

A aplicação das entrevistas se baseou na metodologia de Szymanski (2008), que consiste na entrevista semidirigida realizada a partir de dois encontros, pelo menos. Esse tipo de metodologia apresenta três etapas principais: (1) contato do pesquisador com a área de estudo; (2) realização da entrevista; e (3) restituição das questões para aprofundamento. Esse formato, permite um ambiente mais confortável para os participantes, a fim de que eles discorram livremente sobre seus problemas, sobre o bairro e sobre as inundações. Nesse sentido, buscou-se compreender quais são as estratégias de resposta e adaptação às inundações realizadas no conjunto habitacional, por meio das percepções sobre as ações do poder público e privado.

A partir disso, foi utilizada a metodologia de Souza e Zanella (2010) para a interpretação e compreensão das informações apresentadas pelos entrevistados, a partir de suas próprias experiências e percepções: (1) compreender a percepção e a experiência do entrevistado em face o fenômeno analisado; (2) compreender a percepção quanto à causalidade e responsabilidade pelas inundações; (3) entender as estratégias desenvolvidas pelos moradores e pelo poder público quantos aos riscos de inundação; e (4) entender a ação e participação dos habitantes nas problemáticas socioambientais do Conjunto Habitacional "Moradias Bonilauri".

\section{RESULTADOS E DISCUSSÕES}

\section{Estratégias de resposta e adaptação às inundações}

No âmbito do desenvolvimento de estratégias de resposta pelo poder público, todos os entrevistados relatam a carência de medidas, que visassem à redução da ocorrência de inundações ou a minimização das decorrências associadas a elas. Isto é, constata-se a ausência de políticas públicas para assegurar à população os direitos básicos e, quando são estabelecidas, acabam por ser deterioradas e excludentes, contribuindo para o acréscimo da vulnerabilidade e das injustiças ambientais (SOUSA; LIMA; KHAN, 2015). Por isso, a Liderança 8 recorda que na inundação ocorrida em 1983, onde metade de sua casa caiu no rio Atuba, vizinhos se indignaram com a situação e fizeram protestos, inflamaram pneus e chamaram os jornalistas para descrever o ocorrido.

De outro modo, observa-se que a Liderança 2 aludiu à ineficácia do poder público na erradicação dos problemas de limpeza do rio, por exemplo. A prefeitura utilizava maquinário para desassorear o rio, mas não retirava os resíduos do local, sem fazer a limpeza correta. Deste modo, os próprios moradores tinham que tentar retirá-los para que em uma situação de inundação, os resíduos não fossem para dentro das casas. Por essa razão, a não resolução de problemas recorrentes são vistos como resultado da incompetência do poder público (LIMA; RONCAGLIO, 2001), o que acabam por agravar a condição de risco a que as pessoas estão submetidas.

No âmbito individual/coletivo, verifica-se que quatro entrevistados apresentavam como reação básica a preferência por sair da área de risco em busca de um ambiente mais seguro, com menor ou nula exposição ao risco de inundações, já que o limite de intolerância foi atingido. A Liderança 7 afirma que eles possuem medo, chegando a procurar outra casa acima do rio Palmital, mas não tem condições para se mudar. Tal preferência foi causada pela percepção de que, durante as inundações em que eram atingidos, as casas situadas a $500 \mathrm{~m}$ acima da sua não eram afetadas, pois estavam em uma parte elevada, isto é, exibiam menor exposição ao risco.

$\begin{array}{llllll}\text { Caminhos de Geografia } & \text { Uberlândia-MG } & \text { v. 22, n. } 83 & \text { out./2021 } & \text { p. 01-18 } & \text { Página } 6\end{array}$


Contudo, essas alternativas despontaram-se menos viáveis e, dessa maneira, foram relegadas. Também foi destacado que nessas regiões mais altas, havia muitas invasões. As pessoas chegavam até o local, que "não tinha proprietário", cercavam e construíam suas casas (Liderança 7). Sem espaço disponível e casas a venda nessas áreas, os moradores atingidos tiveram que permanecer nas regiões mais afetadas, principalmente porque para comprar outra casa, estava além das possibilidades financeiras (Liderança 2). Deste modo, ao não obter sucesso em encontrar um lugar seguro em relação ao risco de inundações, os quatro entrevistados permaneceram altamente expostos ao risco, tendo em vista que não havia para onde ir (Liderança 8). Em outras palavras, o aspecto financeiro, novamente, torna-se um impedimento para que as pessoas possam viver em um ambiente seguro e não prosseguir expostas e vulneráveis ao risco híbridos, principalmente as inundações.

Por isso, observa-se que quatro atores sociais tomaram consciência do risco e desenvolveram medidas próprias de resposta às inundações, precisamente as que foram atingidas diretamente, ou seja, houve o regresso do local às condições anteriores ao evento (resiliência). Dentre as medidas elencadas, destacam-se: elevar o nível da casa, criando escadas para acesso, muretas e blocos de concreto. A Liderança 2 cita que a utilização de muretas e blocos é muito comum nas casas, de modo a impedir o avanço da água. Deste modo, elas são instaladas na porta de entrada, na porta do banheiro, na porta da sala, na porta da cozinha e até mesmo nas portas dos quartos. Essas são algumas maneiras encontradas para não perder todos os bens materiais em caso de novas inundações (Liderança 8).

Ou seja, "a noção de resiliência como vimos acima se aplica, mas não significa de maneira alguma a garantia de melhores condições de vida para o enfrentamento aos impactos e dar prosseguimento da vida com dignidade" (MENDONÇA, 2015, p.57). Até mesmo porque tais medidas eram insuficientes para minimizar os impactos das inundações, uma vez que o saneamento básico era deficitário e as águas acabavam por penetrar por meio da rede de esgoto, nomeadamente por meio do ralo do banheiro. Não obstante, um fato mencionado sobre a dragagem manual dos rios deve ser destacado. Há alguns anos atrás, antes da ocupação das casas, as pessoas trabalhavam tirando areia do rio e de seu leito. Em média, a cada dez casas da região, oito trabalhavam para tirar de 2 a 3 caminhões por dia de areia do rio. Esse trabalho de dragagem, de limpeza "formiguinha", foi se perdendo com o tempo, agravando as inundações (Liderança 7).

Por outro lado, nos casos em que as inundações não atingiram o interior da moradia de dois entrevistados, a Liderança 1 e a Liderança 2 enfatizam que jamais foi preciso desenvolver alguma medida de resposta e de adaptação e, por isso, mantiveram o mesmo comportamento exibido no cotidiano. Isto significa que, mesmo com a ocorrência de inundações e graves estragos no entorno e de reconhecerem que estavam expostas ao risco, existe um consentimento de certa maneira indiferente aos riscos suscitados, especialmente pelo fato do limite da consciência não ter sido atingido e também pelo excesso de confiança na própria moradia. Ou seja, para desenvolver alguma medida, é necessário primeiro ser atingido ou até mesmo almejar a atuação do poder público no combate ou na gestão dos riscos. Por isso, não se observa uma consciência pessoal e coletiva no desenvolvimento de procedimentos básicos de prevenção a tais eventos.

Ressalva-se que a ameaça é somente uma das condições para o desenvolvimento de alguma estratégia de resposta e de adaptação às inundações. Isto é, as pessoas podem ou não as desenvolve-las, já que vão estar sujeitos a uma vasta gama de fatores, como o tipo de ameaça, a dimensão, a frequência, as decorrências e os aspectos intrínsecos a cada pessoa (BURTON; KATES; WHITE, 1993; SOUZA; ZANELLA, 2010). Também há a influência da atuação do poder público no desenvolvimento de uma gestão dos riscos que possa contribuir, por um lado, na diminuição da vulnerabilidade e de uma cultura de precaução ou do direito de prevenção às inundações (ARAGÃO, 2009) e, por outro lado, no desenvolvimento de ações de educação ambiental, de forma a expandir a capacidade de resiliência da comunidade e do sistema.

\section{Percepção sobre as estratégias do poder público}

Faz-se imprescindível observar o grau de conhecimento das medidas adotadas pelo poder público destinadas a minimizar ou extinguir as consequências que acompanham as inundações. Dessa maneira, todos os entrevistados têm consciência das modificações desenvolvidas pelo poder público para resolver ou minimizar o problema das inundações no "Moradias Bonilauri". Dentre as medidas mencionadas, destacam-se as estruturais, sobretudo a drenagem, dragagem, boca de lobo, limpeza, o aprofundamento e a ampliação do rio Palmital, a construção de um canal extravasor, manilhamento dos Canais A e B, barreiras de contenção, rede sanitária, asfaltamento e a liberação do Fundo de Garantia por Tempo de

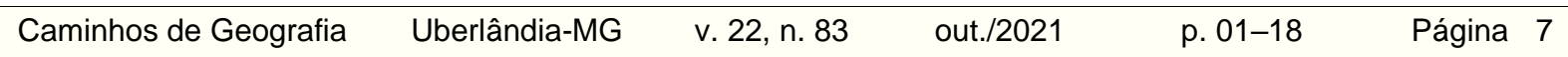


Serviço (FGTS) no evento ocorrido em 2010 (FIGURA 01). Nesse caso, observa-se a partir dos depoimentos a ausência do poder público em desenvolver ações de conscientização e orientação à população.

Figura 01 - Medidas públicas de adaptação às inundações no "Moradias Bonilauri".

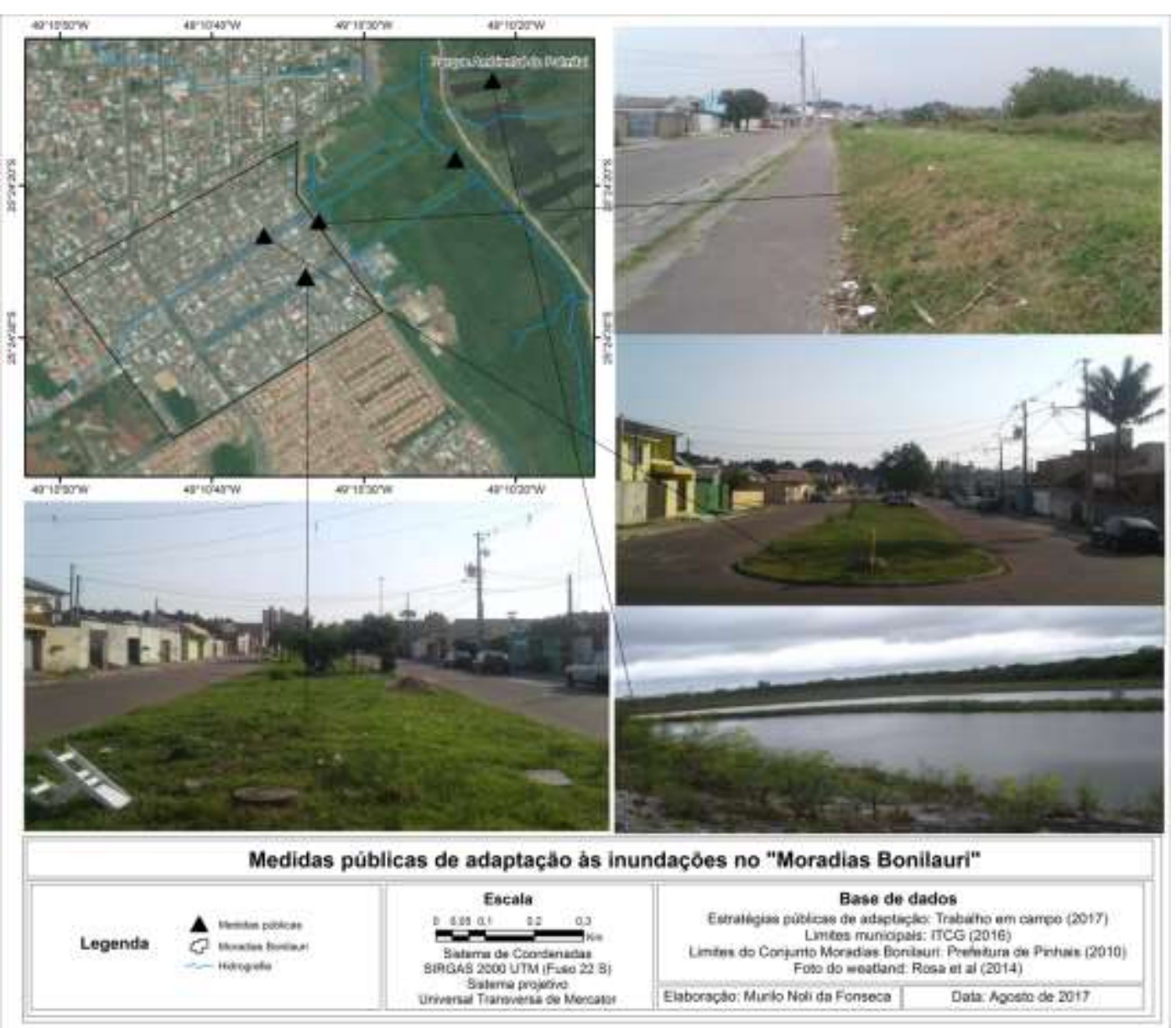

Fonte - os autores.

Cabe destacar, no entanto, que tais medidas foram adotadas exclusivamente após 2011, isto é, há um hiato de 13 anos sem a intervenção do poder público na implantação de medidas que tendessem a redução da vulnerabilidade e as implicações associadas às inundações, por isso, são prontamente lembradas e detalhadas pelos entrevistados. Eles destacam que quando chegaram ao local nada era asfaltado, com tanto barro que quando se pisava, afundava. A solução era sair com sacola nos sapatos ou descalço, levando uma garrafa de água para limpar os pés (Liderança 8). Isto é, as problemáticas socioambientais desse espaço derivam da precariedade de infraestrutura e serviços urbanos, o que resulta em uma maior vulnerabilidade e exposição aos riscos (ALVES; TORRES, 2006). Logo, o asfaltamento das ruas possibilitou a redução do acúmulo de água e da poeira suscitada em ocasiões de tempo seco e a incidência de doenças sensíveis e do sistema respiratório, e maior segurança.

O trabalho da prefeitura, em relação à dragagem, foi realizado entre 2010 e 2012. Em 2012 se iniciou a revitalização. Essa questão de criação dos extravasores e outras áreas, com a implantação do Parque Ambiental na margem esquerda do rio Palmital, ajudou bastante a região (Liderança 7).

Curiosamente, todos os entrevistados relacionam tais medidas com a não ocorrência de inundações desde o ano de 2014, o que corrobora a confiança na erradicação do risco e na impossibilidade de novos acontecimentos e que pode inibir a implantação de medidas de prevenção. A Liderança 4 destaca que desde que o prefeito mandou drenar o rio com bastante máquinas, não se tem mais enchentes a anos. Desde 2014 é que a situação melhorou completamente, pois antes se perdia tudo, e agora parece que não será mais uma preocupação (Liderança 2).

$\begin{array}{llllll}\text { Caminhos de Geografia } & \text { Uberlândia-MG } & \text { v. 22, n. } 83 & \text { out./2021 } & \text { p. 01-18 } & \text { Página } 8\end{array}$


Já a Liderança 5 frisa que o problema da enchente praticamente foi resolvido, só depende do tempo para confirmar. A Liderança 6 destaca que na frente da sua habitação existia uma valeta ao ar livre, chamada de Canal A, e consistia em um dos principais lugares por onde inundava, mas que recentemente foi manilhado pela prefeitura com verba do Programa de Aceleração do Crescimento (PAC) (FIGURA 02). Ele enfatiza que as obras do poder público amenizaram ou até extinguiram as inundações, pois fazem anos que as enchentes não acontecem. No entanto, acrescenta que as ruas foram rebaixadas cerca de $50 \mathrm{~cm}$ para fazer o asfalto. Deste modo, com chuvas fortes, as ruas alagam.

Figura 02 - Afluente do rio Palmital antes e após o manilhamento.

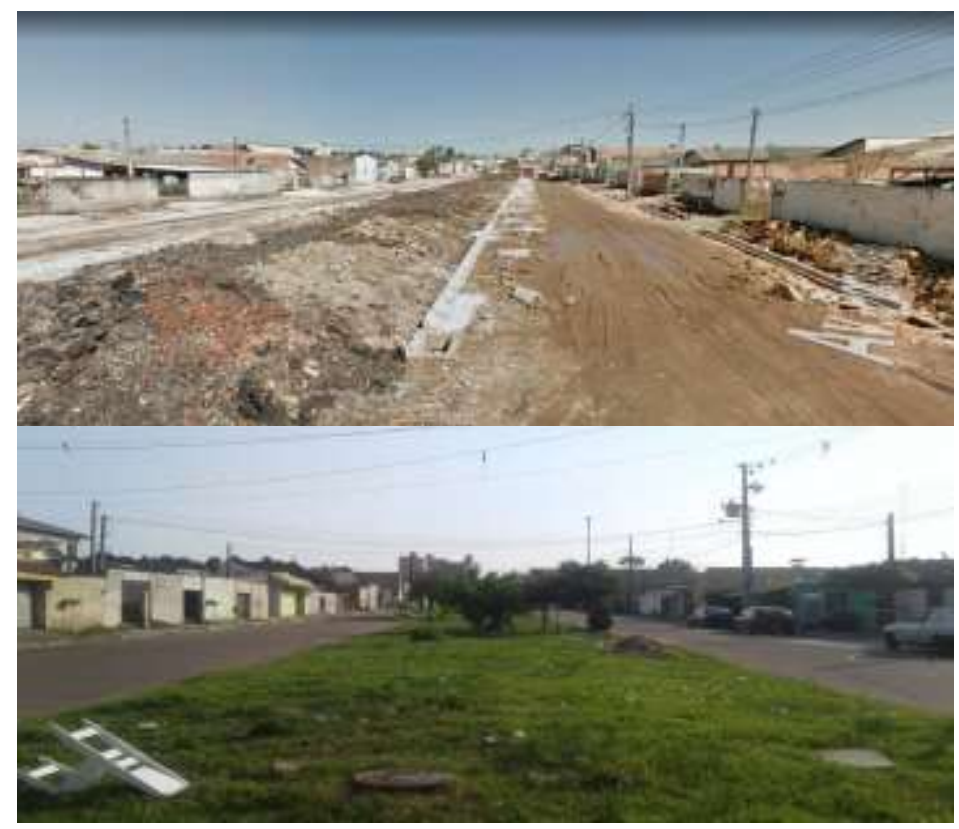

Fonte - os autores, com base na visualização do Google Street View.

A Liderança 5 ainda acrescenta que, além da drenagem concretizada pela prefeitura, não houve precipitações ininterruptas e com magnitude suficiente para ocasionar inundações. Já a Liderança 8 descreve que se não fosse a implantação de manilhas o problema ainda continuaria a ocorrer. Nas inundações ocorridas em 2010, a Liderança 8 menciona que foi liberado o fundo de garantia (FGTS) para que as pessoas pudessem elevar o nível das casas, a fim de que isso resolvesse o problema da água entrar nas casas. Além do mais, a Liderança 7 ressalta o desenvolvimento de medidas de redução dos riscos pela prefeitura, mas aponta a ineficácia dos municípios que partilham os rios Atuba, Palmital e Iraí. Para ela, embora faça alguns anos que não entra mais água dentro das casas, agora alagam as ruas. Além disso, Pinhais tem problema com os municípios vizinhos: de tal modo que os principais rios da região também passam por Curitiba, Colombo e São José dos Pinhais.

Para tentar resolver esse problema, foi realizada uma audiência dos moradores com o prefeito. Os entrevistados citam que eles gostariam de poder fazer a limpeza do rio dentro dos limites dos outros municípios, mas que isso não é possível sem autorização. Sendo assim, a água extravasa em Pinhais, já que o município é como uma ilha, cercado por rios, e os moradores precisam continuar nessa situação. Por isso, cada município tem que fazer sua parte, pois apenas um não vai conseguir resolver esse problema (Liderança 7).

Dessa maneira, apesar de reconhecerem a minimização da ocorrência de inundações, observa-se que sete atores sociais sublinham não somente o desenvolvimento de medidas de resposta às inundações pelo poder público, mas que estas sejam realizadas com assiduidade, no sentido de reduzir o risco de inundações na área. Se não houver manutenção das áreas verdes implementadas, o rio vai começar a encher novamente (Liderança 5), pois ele é muito raso, sendo muito fácil para sujar e encher de terra novamente (Liderança 1).

Esse pensamento também robustece a crença no poder público e a maioria não percebe a importância do próprio indivíduo e do coletivo na tomada de decisões e na minimização dos problemas. A Liderança 5 ,

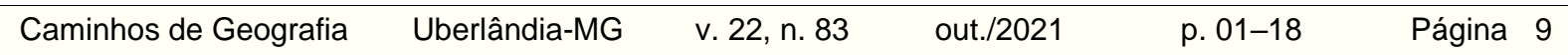


por exemplo, afirma que se a prefeitura conseguir manter as medidas de mitigação, não vai mais ocorrer enchentes. Isto é, as medidas estruturais, sobretudo as obras de engenharia, como a dragagem e o Parque Palmital, normalmente, fornecem uma maior sensação de segurança aos indivíduos que residem em áreas de risco, quando confrontadas com as medidas não estruturais. Os moradores reconhecem que devido à conformação do terreno as únicas medidas possíveis de minimizar as inundações são aquelas desenvolvidas pelo poder público, já que acreditam não ter muito o que fazer, pois o lugar em que moram é muito baixo. Então, se a drenagem não resolver, não se sabe o que poderia ser feito (Liderança 4).

Por outro lado, apenas uma pessoa descreve a necessidade de mudar o foco das medidas de resposta, isto é, desenvolver menos medidas estruturais e mais medidas não estruturais, especialmente a implantação de um saneamento básico apropriado, pois, além de contribuir para aprimorar o escoamento das águas pluviais, diminuiria as enfermidades transmitidas pelo meio hídrico, como a leptospirose, que é uma doença provocada pela urina do rato e, devido às inundações, facilita o contato das pessoas com a água contaminada. Evoca-se também um estreitamento no contato entre o poder público e a comunidade, o que deixa claro que a sua ausência no "Moradias Bonilauri" acende um sentimento de exclusão, suscitando insatisfação em algumas pessoas, que demandam uma maior cautela pelo poder público. Para a Liderança 2, abrir o rio é a única coisa que o poder público faz. Eles não pensam em verificar as outras áreas do rio ou de fazer o saneamento básico adequado. Deste modo, ela acredita que o problema nunca vai ser resolvido (Liderança 2).

\section{DESENVOLVIMENTO DE ESTRATÉGIAS PRIVADAS DE ADAPTAÇÃO}

Faz-se necessário observar e compreender quais foram as reações dos atores sociais perante as inundações e se desenvolveram alguma medida de prevenção e/ou para reduzir a ocorrência de inundações e minimizar ou até mesmo extinguir as consequências atreladas a estas (WHITE, 1974). Assim, ao serem arguidos se houve alguma alteração na comunidade após a ocorrência de inundações, cinco entrevistados contam ter percebido reações da comunidade, sobretudo com protestos e a venda das moradias. Muitos moradores ficavam revoltados com a frequência das inundações (Liderança 5), por isso havia muitos protestos, até nas principais avenidas da cidade. As pessoas iam até na frente da prefeitura fazer panelaço (Liderança 4).

A revolta das pessoas é principalmente devido a seus diretos básicos de cidadão. Alguns moradores venderam as casas e foram morar em invasões de municípios vizinhos como Piraquara. Mesmo que as casas sejam doadas, as pessoas precisam pagar os impostos como qualquer outro morador de Pinhais. Desta forma, eles sentem que assim como as outras comunidades não possuem enchentes, eles também têm o direito de viver em um lugar que isso não ocorra.

Observa-se uma impotência em encontrar medidas coletivas para a minimização da ocorrência de inundações ou das consequências associadas a estas, fazendo com que aceitem passivamente o risco e desenvolvam ações somente durante o evento. O que os moradores faziam era limpar as casas após as inundações e continuar no lugar, pois poucos iam brigar pelos direitos na prefeitura (Liderança 2). As enchentes também resultam em muita solidariedade, unindo as pessoas, de tal modo que todos os vizinhos se ajudam (Liderança 7). Por outro lado, um entrevistado descreveu que não houve mudanças de comportamento individual, pois todos continuaram no mesmo ritmo, sem mudanças comportamentais. Ele cita que não foi visto nenhuma alteração cultural, já que as pessoas continuaram jogando detritos, por exemplo (Liderança 6).

Cinco atores sociais também adotavam medidas de resposta durante a iminência de uma inundação, curiosamente as que foram reassentadas da área de risco para o Conjunto "Moradias Bonilauri". Já as outras três pessoas descrevem que não adotavam nenhuma forma de cuidado, pois o interior de suas moradias não era penetrado e, por isso, o limiar de intolerância não foi atingido. Dentre as medidas adotadas, destaca-se depositar saco de areia em cima do ralo do banheiro, barricada de areia no portão, parede de tijolo, mureta e levantar os móveis. Embora não existam garantias de sua eficácia, o que pode suscitar uma falsa sensação de segurança, tais medidas poderão reduzir a entrada de água no interior da moradia, portanto, minimizar os prejuízos.

Quando a água começa a entrar no portão, os moradores iniciam o processo de erguer alguns móveis, utilizando tijolos (Liderança 7). Depois disso, é necessário improvisar, ver na hora o que é possível levantar e tentar salvar o possível, rezando para que a água não suba mais do que o esperado (Liderança 8). Em alguns casos, já se deixava tudo preparado, sacos de cimento e rodos de água, armazenando apenas o essencial, como poucos documentos e alimentos, largando todo o resto (Liderança 2).

Além dessas medidas, que possuem como propósito salvaguardar bens materiais, há de destacar-se que em condições adversas muitas pessoas rejeitam sair do seu domicílio para ir a um abrigo ou a casa de um parente. Tal circunstância ocorre, especialmente, pela dependência dos familiares, amigos ou vizinhos e porque possuem o temor de que a moradia seja furtada. Por isso, a Liderança 2 salienta que em muitos

$\begin{array}{llllll}\text { Caminhos de Geografia } & \text { Uberlândia-MG } & \text { v. 22, n. } 83 & \text { out./2021 } & \text { p. 01-18 } & \text { Página } 10\end{array}$


casos foram imprescindíveis a persuasão de pessoas mais velhas a afastar-se da sua casa por causa da ameaça das inundações. Ela diz que, os idosos são mais teimosos por não quererem abrir mão de suas casas, ressaltando que já tentou diversas vezes pedir para que eles saíssem das casas e até ficassem na sua até a chuva passar.

Por outro lado, é importante lembrar que desde a construção do "Moradias Bonilauri" em 1998 ocorreram diversas inundações, mas, como comentado anteriormente, o poder público passou a desenvolver medidas de resposta exclusivamente após 2011, uma intermitência de 13 anos à mercê das medidas de redução e/ou minimização do risco. Em outras palavras, perante a ausência do poder público nas problemáticas presentes no "Moradias Bonilauri", observa-se que cinco atores sociais desenvolveram estratégias próprias de resposta às inundações de acordo com a sua vivência/experiência com o fenômeno, especialmente as que descreveram a penetração da água no interior da casa, e não com a assistência do poder público ou de técnicos/arquitetos/engenheiros, o que pode estar atrelada ao baixo poder aquisitivo. Nesse caso, inúmeros estudos têm corroborado que em áreas com melhores condições socioeconômicas as intervenções em edificações são fundamentalmente orientadas por profissionais da área (ARAÚJO, 2013).

Dentre as medidas elencadas, sobressai o aterramento, rampas de acesso, e a paredes de proteção (FIGURA 03). O aterramento é uma medida que tem como propósito elevar o pavimento no interior das habitações de modo a prevenir a penetração da água no seu interior, assim como os próprios muros. São medidas simples e que não estão sujeitos aos custos elevados, por conseguinte, podem ser concretizadas pelos próprios moradores, assim como já foi assinalado por diversos autores como Zanella (2006) e Mendonça, Buffon e Goudard (2015). A partir do momento que uma pessoa começou a erguer a casa, todas seguiram o mesmo exemplo, pois se fossem depender da prefeitura, todos estariam embaixo d'água. É justamente por isso que ninguém mais possui a moradia no nível da rua, devido as inundações (Liderança 8). Esta liderança também salienta que inúmeras pessoas venderam a casa e foram embora do conjunto, porque estavam cansadas de perder todos os móveis a cada quatro ou cinco meses.

Figura 03 - Exemplos de moradias em que foram adotadas medidas privadas de adaptação no Moradias Bonilauri.

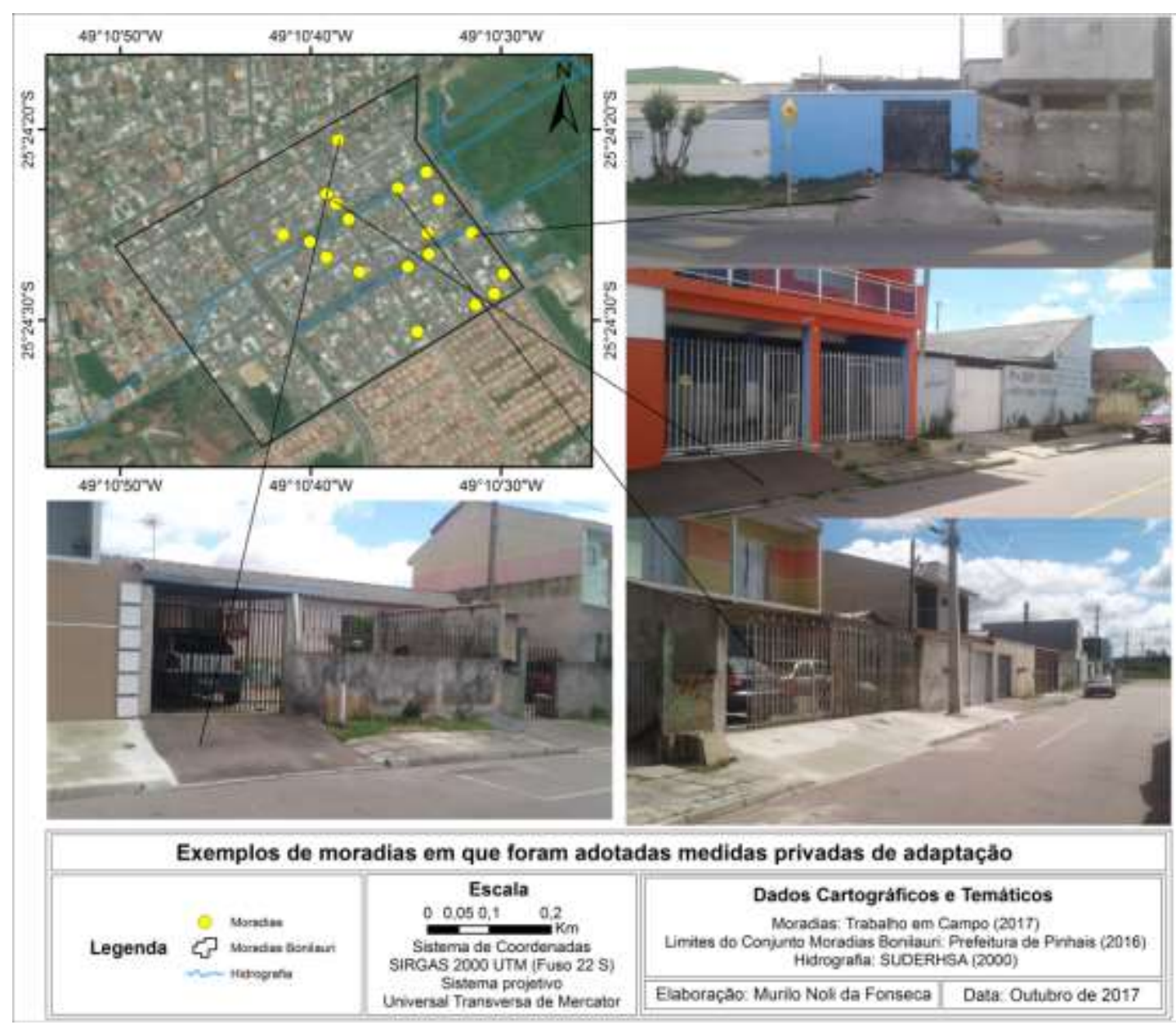

Fonte - os autores.

Caminhos de Geografia $\quad$ Uberlândia-MG $\quad$ v. 22, n. 83 $\quad$ out./2021 $\quad$ p. 01-18 $\quad$ Página 11


Em alguns casos, o aterramento forçou às pessoas a levantarem rampas de entrada à própria moradia, especialmente para aquelas que possuem automóveis, ou seja, com um poder aquisitivo maior e que são, na maior parte das ocasiões, pessoas que não foram reassentadas de uma área de risco para o "Moradias Bonilauri". Em média, foi utilizado dois caminhões de terra para elevar a casa (Liderança 4), iniciando o aterramento da parte de trás do terreno para a frente. Isso foi realizado logo após a inundação de 2010, evitando que essas casas fossem atingidas novamente pela água. Entretanto, os vizinhos que não puderam fazer o mesmo ficaram embaixo da água, com a rua parecendo um rio (Liderança 8). Destaca-se que mesmo elevando o nível da casa, já ocorreu de a água entrar e danificar os bens materiais. Por isso, se houvesse condição, o melhor seria construir um novo andar e deixar a parte de baixo da casa vazia, ou com apenas uma mesa por exemplo. Assim não estragaria mais nada (Liderança 7).

Portanto, observa-se que as habitações, nas quais foram adotadas tais medidas, apresentam uma ampla elevação, o que denota a dimensão das inundações ocorridas (FIGURA 04). Como fruto disso, observa-se um descompasso indiscutível entre o nível das casas e da calçada que, em alguns casos, chega a alcançar entre 30 e $60 \mathrm{~cm}$ de diferença em relação ao nível da rua. Logo, as calçadas não apresentam uma homogeneidade e acabam suscitando inúmeros problemas de acessibilidade, como é o caso das pessoas com deficiência física, que foi mencionada por uma das lideranças como um dos problemas no Bonilauri. Além do mais, percebe-se a elevação do nível do solo à entrada de domicílios individuais, sobretudo em áreas com indivíduos de baixo poder aquisitivo. Assim, tais medidas visam minimizar os impactos da água, evitando a entrada no interior da moradia na iminência das inundações (MENDONÇA; BUFFON; GOUDARD, 2015).

Figura 04 - Descompasso entre a rampa de acesso/escadarias nas casas e a calçada.

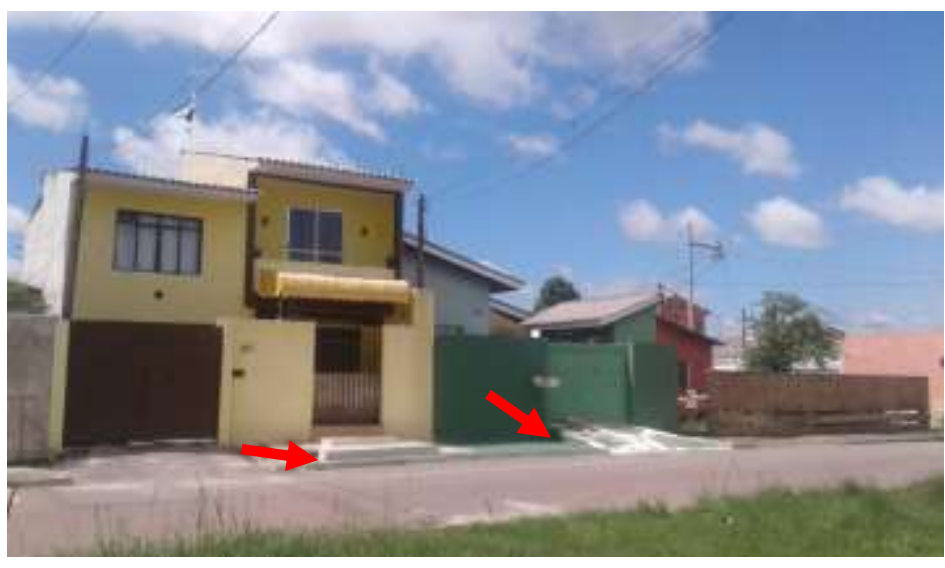

Fonte - os autores.

Cabe destacar, que das cinco pessoas que asseguraram ter feito aterramento e levantado a habitação, quatro os fizeram após serem atingidos pelos eventos de 2010, quando houve a disponibilização do FGTS para a implantação de tal medida, o que confirma, por um lado, a assertiva mencionada de que não houve ação de prevenção pelas pessoas que foram reassentadas e, por outro, da vulnerabilidade social a que se encontram submetidos. Porém, essa área continua exposta à situação de risco, já que são caracterizadas por precárias condições de vida (vulnerabilidade socioambiental) dos indivíduos que nelas vive. Tal comprovação ratifica a seguinte declaração: "a noção de resiliência como vimos acima se aplica, mas não significa de maneira alguma a garantia de melhores condições de vida para o enfrentamento aos impactos e dar prosseguimento da vida com dignidade" (MENDONÇA, 2015, p.57).

Contudo, somente dois entrevistados narram ter elevado o nível da casa ou feito um segundo andar antes de serem atingidos por inundações, isto é, desenvolveram ações de prevenção e, por isso, garantem que jamais foram atingidos por tais eventos. Foi realizada uma elevação de $70 \mathrm{~cm}$ acima do nível da rua, pois se a casa ainda estivesse baixa, a água entrava de $30 \mathrm{a} 40 \mathrm{~cm}$ para dentro da casa (Liderança 6). Quando arguido sobre o motivo pelo qual resolveu adotar tal medida ele assegura que foi por uma questão de precaução, pois infelizmente não se tem controle sobre a natureza.

Contudo, nem todas as pessoas conseguiram bancar o aterramento e erguer a casa ou planejar outra medida de resposta aos eventos de inundação, embora compreendam que tais eventos podem resultar em prejuízos expressivos, mostrando-se indiferentes em função da carência financeira ou até mesmo por

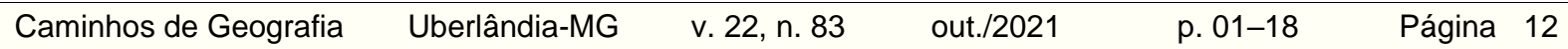


desconhecerem os riscos ou por comodismo (ABREU; ZANELLA, 2015). A maioria das pessoas que foram realocadas da beira dos rios, não tem condição financeira para mexer nas casas (Liderança 7). Essa circunstância ocorre principalmente nas habitações mais próximas aos afluentes do rio Palmital que apresentam uma maior vulnerabilidade ao risco da inundação e também aquelas que apresentam uma menor exposição (FIGURA 05). Por essa razão, tem muita gente que continua a reclamar quando a chuva é forte, porque a água entra nas casas de quem não conseguiu aterrar (Liderança 8).

Neste sentido, a Liderança 2 constituiu uma das pessoas entrevistadas que não conseguiram elevar inteiramente o nível da casa, especialmente pelo desconhecimento de medidas e por ter feito um segundo pavimento para os filhos. Quando foi feita a construção, foi feito um aterro, mas não o suficiente para que a água não entrasse mais. Se essa situação tivesse sido pensada antes de construir, daria para fazer uma rampa alta, mas como não foi prevenido, terá de ficar desse jeito mesmo. Porém, ela ainda frisa que depois das obras da prefeitura, não está mais ocorrendo inundações, então não precisa mais se preocupar com isso.

Além de aterrar o terreno e elevar o nível da casa, algumas pessoas fizeram intervenções no interior da própria moradia, o que reforça outra vez a autoconstrução. Foi feita a elevação dentro da casa, principalmente para a água não voltar para o esgoto. Então os encanamentos passar por baixo da casa e saem direto na rua (Liderança 2). Outra alteração é com o acompanhamento da elevação da rua. $\mathrm{Na}$ medida em que a prefeitura eleva as ruas para o asfalto, também se eleva o nível da casa (Liderança 1). A autoconstrução encontra-se sujeito ao poder aquisitivo de cada de indivíduo, de modo que uma pessoa com baixa renda irá implantar aos poucos as medidas de adaptação e em alguns casos pode gerar incidentes. Nesse caso, a Liderança 1 já realizou esse processo dez vezes, mas ainda falta elevar o nível de alguns cômodos que não foram possíveis anteriormente.

Figura 05 - Exemplos de moradias que não fizeram o aterramento.

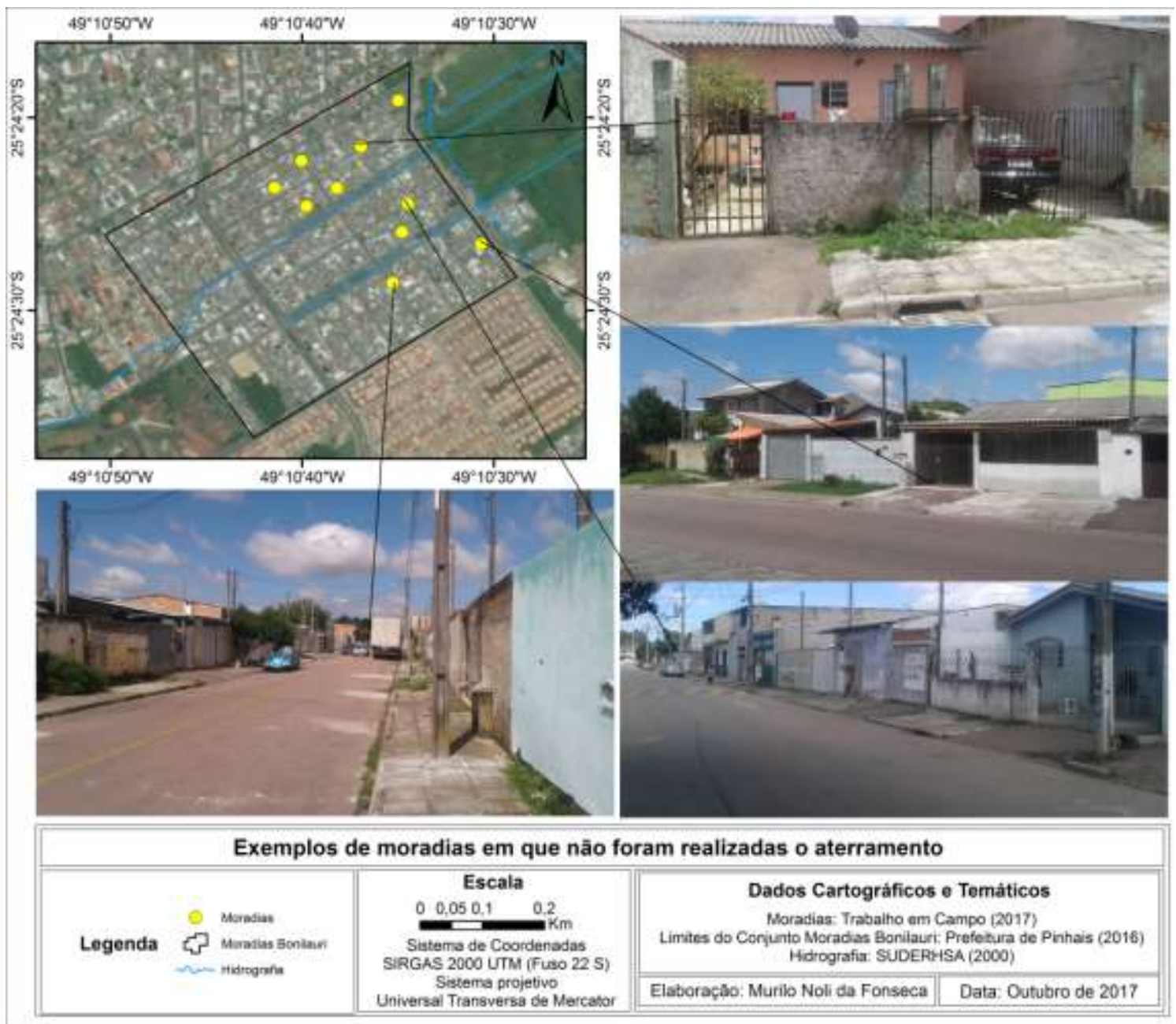

Fonte - os autores.

$\begin{array}{lllll}\text { Caminhos de Geografia } \quad \text { Uberlândia-MG } & \text { v. 22, n. } 83 & \text { out./2021 } & \text { p. 01-18 } & \text { Página } 13\end{array}$


Destaca-se que seis entrevistados acreditam que o seu domicílio pode ser atingido outra vez por uma inundação, ou seja, mesmo com as medidas individuais e do poder público essas pessoas se sentem vulneráveis ao risco de enchentes. Logo, o principal motivo para que isso aconteça seria a ausência do poder público na manutenção das medidas estruturais, como é a dragagem do rio Palmital. Percebe-se que as pessoas não se colocam como parte importante no processo de minimização dos problemas decorrentes das inundações. Se a gestão atual não der a mesma atenção que as anteriores (Liderança 7), como o caso da limpeza do rio, que não se tem visto mais maquinários trabalhando, isso começa a preocupar os moradores, pois se for possível ver o fundo do rio significa que ele já está raso novamente (Liderança 8). E a Liderança 4 associa a dragagem com a intensidade e frequência da chuva, pois se a precipitação for contínua e intensa, a água vai atingir a região novamente, já que a altura do rio é de apenas 3 metros.

Por outro lado, duas pessoas asseguram que a sua casa dificilmente pode ser atingida por uma inundação. Em outras palavras, suas moradias se encontram livres de qualquer possibilidade de ocorrência de inundações, mesmo que essa aconteça no terreno. A justificativa dada é que o interior das suas casas não havia sido atingido pelos eventos anteriores, pois haviam elevado o nível da moradia ou construído um segundo andar. A Liderança 6, por exemplo, corrobora esse pensamento ao assegurar categoricamente que pela questão de ter elevado a residência e pelo que se percebe a partir dos alagamentos, acredita-se que na sua casa não deve ser atingida. A não ser que aconteça uma proporção muito grande de chuva, como por exemplo, 2 ou 3 meses seguidos.

\section{Possibilidades de pensar a redução ao risco de inundações}

Quando arguidos sobre o que poderia ser feito no Conjunto "Moradias Bonilauri" para minimizar e/ou resolver o problema das inundações, sete entrevistados arrogam ao poder público o desenvolvimento de estratégias de resposta. Jacobi (2006) salienta que o fato de as pessoas imputarem ao poder público a responsabilidade pela procura de soluções dos problemas representa a desinformação e o baixo nível de consciência da importância no processo de minimização das inundações, além da ausência de incentivo coletivo à participação e ao envolvimento da população na gestão municipal.

Dessa forma, as medidas que deveriam ser tomadas pelo poder público são fundamentalmente estruturais: a realização de dragagens com assiduidade e a construção de um canal extravasor, o que sugere certa eficácia de tais medidas ou até mesmo o desconhecimento de outras formas de minimização das inundações. A Liderança 4 relata que a prefeitura deve manter a dragagem do rio, porque são eles os responsáveis por tomar as melhores medidas, já que entendem mais desses processos do que os moradores. A mesa afirmação é levantada pela Liderança 3 que relatou que se não continuarem a fazer o desassoreamento do rio, as inundações vão voltar a ocorrer e os moradores vão perder tudo outra vez.

A Liderança 2 acredita que o poder público deva fazer intervenções na estrutura do "Moradias Bonilauri" e não apenas no rio Palmital. Conforme ela, os gestores só fazem a dragagem do rio, mas não pensam em fazer melhorias na infraestrutura de saneamento, por exemplo. Ela acrescenta que seria ideal se fizessem um novo sistema de drenagem perto do outro, porque já faz tempo desde a construção da última estrutura. Porém, uma das pessoas entrevistadas acredita na impossibilidade de fazer alguma coisa para minimizar as inundações, pois Deus manda as chuvas e tudo ocorre conforme deve ser. No entanto, ela destaca que se o motivo das inundações for devido a abertura de represas, é contra (Liderança 1). Ou seja, há uma confiança de que, infelizmente, as inundações e suas consequências são atos de Deus, algo que pouco pode ser feito a respeito (BERGH; FAURE, 2006).

Já a Liderança 6 enfatiza que não teria como evitar as enchentes, a não ser que fizessem um canal extravasor. A Liderança 7 imputa à população as medidas que visam minimizar as inundações. Para ela, cabe a cada pessoa, de forma individual, a conscientização da limpeza. Não jogar móveis ou resíduos em geral na rua, limpar as bocas de lobo em frente das casas que permanecem entupidas de terra e de sujeira, juntar pacotes de lixo e jogar nas lixeiras, entre outros exemplos. Ela afirma ainda que esse tipo de atitude deve ocorrer em paralelo a prefeitura municipal, pois reclamar do poder público é mais fácil do que mudar suas próprias atitudes.

Nesse sentido, quatro atores sociais afirmam estar preparados para a ocorrência de uma inundação, especialmente por terem presenciado e vivenciado diversas delas, ou seja, tornou-se um hábito. A Liderança 5, por exemplo, conta que quando começa a chover as pessoas já ficam na janela olhando o rio para ver se está enchendo. Dessa forma, os moradores vivem nesse ritmo de sempre estar cuidando quando acontecer novamente. Ela também relata que a comunidade já participou de diversas reuniões da

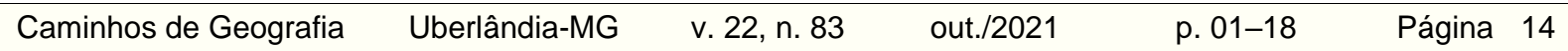


Companhia de Saneamento do Paraná (SANEPAR) para aprender como cuidar da água, realizar a separação dos resíduos e entender como a reciclagem pode ajudar a prevenir as enchentes. Depois que a SANEPAR realizou essa capacitação, foi percebido que os moradores estão respeitando mais a disposição correta dos resíduos.

Ao serem perguntados sobre estarem preparados quanto aos casos de inundação, as Lideranças 4 e 7 afirmam que nessas situações as pessoas jamais devem afirmar estarem preparadas, pois nunca se sabe o que deverão enfrentar. Espera-se que as inundações não voltem a ocorrer, mas se isso acontecer, o jeito será tentar salvar tudo o que conseguirem e ter paciência. A Liderança 2 descreve que estando nessa região é necessário andar preparado todos os dias, permanecendo em alerta o tempo inteiro, mas que é uma das pessoas que já se adaptou a tudo isso, estando acostumada com a situação. Por outro lado, quatro entrevistados afirmaram não estarem preparados para uma nova inundação, especialmente por acharem que não se pode controlar a força da natureza (Liderança 1) e por motivos religiosos (Liderança 8), ratificando que há pessoas que aceitam de forma passiva os riscos a que se encontram (SOUZA; ZANELLA, 2010).

\section{CONSIDERAÇÕES FINAIS}

A partir da realização da pesquisa, foi possível responder às questões problema, compreendendo as medidas adotadas pelo poder público e iniciativas privadas para tentar solucionar o problema das inundações no conjunto habitacional, assim como entendendo a percepção das pessoas quanto sua segurança a partir das estratégias implementadas. Deste modo, é possível concluir que o objetivo geral da pesquisa, de analisar as estratégias de resposta e de adaptação do "Moradias Bonilauri" frente ao enfrentamento do risco de inundações no município de Pinhais, foi atendido.

Inicialmente, é importante destacar a limitação da pesquisa: a dificuldade para encontrar pessoas dispostas a participar do presente estudo. Nesse caso, muitas pessoas se sentiram desconfiadas ou tiveram medo de falar sobre o assunto, salvo os casos que não quiseram participar por não receberem nada em troca das respostas. Deste modo, para futuras pesquisas, é importante buscar por líderes comunitários que possam ajudar em um alcance maior de participantes.

De maneira geral, mesmo estando conscientes dos riscos de inundações, muitos atores sociais os ignoram e continuam vivendo com eles sem apresentar reação no sentido de se mudar para um local mais seguro ou pelo menos adotar medidas que possam minimizar os riscos ou ainda de lutar pelo apoio do poder público. Isso ocorre principalmente porque o baixo nível de conhecimento e a ausência de condições econômicas favoráveis, em alguns casos até mesmo comodismo, muitas vezes impelem as pessoas a aceitarem os riscos, agindo passivamente diante deles.

Por outro lado, foi possível observar que as medidas adotadas por iniciativas públicas e privadas interferem diretamente na vida dos moradores do conjunto habitacional. As pessoas que conseguiram adotar alguma medida somente o fizeram após os eventos de 2010, quando houve a disponibilização do uso do FGTS, mostrando que não houve nenhuma ação de prevenção pelas pessoas que foram reassentadas e da vulnerabilidade a que se encontram submetidos.

Mesmo assim, observa-se a impotência das pessoas em encontrar medidas coletivas para a minimização da ocorrência de inundações ou das consequências associadas a estas, fazendo com que aceitem passivamente o risco e desenvolvam ações tão somente durante o evento. Todos os entrevistados relacionam tais medidas com a não ocorrência de inundações desde o ano de 2014, o que corrobora a confiança na erradicação do risco e na impossibilidade de novos acontecimentos, e pode inibir a implantação de medidas de prevenção e até mesmo atrofiar as medidas existentes. Os próprios moradores reconhecem que, devido à conformação do terreno, as únicas medidas possíveis de minimizar as inundações são as desenvolvidas pelo poder público.

Logo, todos os entrevistados têm consciência das mutações desenvolvidas pelo poder público para resolver ou minimizar o problema das inundações no "Moradias Bonilauri". Dentre as medidas mencionadas se destacam, especialmente, as estruturais. Por outro lado, observa-se a partir dos depoimentos uma ausência do poder público em desenvolver ações de conscientização e orientação à população. No entanto, a criação do Parque do Palmital, na margem esquerda do rio Palmital, pode reforçar a existência de duas realidades urbanas com precaríssimas similitudes. De um lado do rio há o "Moradias Bonilauri", marcado pela degradação e pela vulnerabilidade ao risco de inundações. De outro há o Alphaville Graciosa, um condomínio fechado de alto padrão e com baixa vulnerabilidade ao risco.

$\begin{array}{llllll}\text { Caminhos de Geografia } & \text { Uberlândia-MG } & \text { v. 22, n. } 83 & \text { out./2021 } & \text { p. 01-18 } & \text { Página } 15\end{array}$


Além disso, na busca por compreender se a implementação destas estratégias trouxe segurança para a vida das pessoas, em muitos casos, os atores sociais acreditam que o seu domicílio pode ser atingido novamente, mesmo com as medidas individuais e do poder público essas pessoas se sentem vulneráveis ao risco de inundações. Logo, o principal motivo para que isso aconteça seria a ausência do poder público na manutenção das medidas estruturais, como é a dragagem do rio Palmital. Por essa razão, percebe-se que as pessoas não se colocam como parte importante no processo de minimização dos problemas decorrentes das inundações. Por outro lado, duas pessoas asseguram que a sua casa dificilmente pode ser atingida por uma inundação, como um evento que afetaria somente outras pessoas da área e não elas mesmas e, assim, tendem a permanecer vivendo da mesma forma, isto é, que suas moradias se encontram livres de qualquer possibilidade de ocorrência de inundações, mesmo que essa aconteça no terreno.

Conclui-se que, um dos principais pontos identificados como falha durante a aplicação das entrevistas, são para ações voltadas à educação ambiental e à sensibilização dos moradores, já que o primeiro passo para a redução do risco passa necessariamente pelo envolvimento das pessoas, com base na sua informação sobre os riscos. A educação é essencial nas transformações individuais e sociais e nas mudanças de atitude para com o meio ambiente, revelando-se também como um importante instrumento para alcançar uma sociedade mais justa e ambientalmente equilibrada.

Desta forma, a presente pesquisa traz como contribuições: (1) a percepção dos riscos ambientais locais em contraste aos eventos resultantes das mudanças climáticas; (2) o aprofundamento na compreensão da convivência com o risco de inundação; e (3) a avaliação de como estratégias tomadas por iniciativas públicas e privadas afetam a vida de moradores nessa situação. Como pesquisas futuras, sugere-se que sejam estudadas novas medidas de mitigação dos impactos existentes no conjunto habitacional. Como principais vertentes, é possível analisar se novas medidas estruturais são possíveis de serem realizadas; se parcerias intermunicipais para medidas de contenção em municípios a jusante são viáveis financeiramente; e estudos que sirvam de base para o poder público e a iniciativa privada, para a recuperação do local e, consequentemente, o reassentando das famílias para áreas disponíveis e fora de risco.

\section{REFERÊNCIAS}

ABREU, N.J.A., ZANELLA, M.E. Percepção de risco de inundações: estudo de caso no bairro Guabiraba, Maranguape-Ceará. Revista OKARA: Geografia em debate, vol.9, n.1, p.90-107, 2015.

ALEKSIÉTICH, S.A. Svetlana Alexievich: "a história colectiva é uma grande mentira". Portugal: Público, 2016. Disponível em: <https://www.publico.pt/2016/04/27/culturaipsilon/noticia/svetlana-alexievich-ahistoria-colectiva-e-uma-grande-mentira-1730225> Acesso em: 15 mai. 2020.

ALVES, H. P. F.; TORRES, H. G. Vulnerabilidade socioambiental na cidade de São Paulo: uma análise de famílias e domicílios em situação de pobreza e risco ambiental. São Paulo em Perspectiva, v. 20, n. 1, p. 44-60, 2006.

ARAGÃO, A. A prevenção de riscos em Estados de direito ambiental na União Europeia. Coimbra: Observatório do Risco, Centro de Estudos Sociais, Universidade de Coimbra, 2009.

BACCHIEGGA, F. Mudanças climáticas como um risco construído ou percebido: análise da produção teórica de J. Hannigan e O. Renn no debate da sociologia Ambiental. Desenvolvimento e Meio Ambiente, v. 42, p. 37-51, 2017. https://doi.org/10.5380/dma.v42i0.48696

BENISTON, M., STEPHENSON, D. B. Extreme climatic events and their evolution under changing climatic conditions. Global and planetary change, n. 44, p. 1-9, 2004.

https://doi.org/10.1016/i.gloplacha.2004.06.001

BERGH, R. V; FAURE, M. Compulsory Insurance of Loss to Property caused by natural Disasters: Competition or Solidarity? World Competition, v. 29, n.1, p. 25-54, 2006.

BOTKIN, D. B.; KELLER, E. A. Ciência Ambiental. Terra, um Planeta Vivo. 7 ed. Rio de Janeiro: LTC, 2011.

BRODY, S. D., ZAHRAN, S., VEDLITZ, A., GROVER, H. Examining the relationship between physical vulnerability and public perceptions of global climate change in the United States. Environmental and Behavior, v.40, n.1, p.72-95. 2008. https://doi.org/10.1177/0013916506298800

$\begin{array}{llllll}\text { Caminhos de Geografia } & \text { Uberlândia-MG } & \text { v. 22, n. } 83 & \text { out./2021 } & \text { p. 01-18 } & \text { Página } 16\end{array}$


BURTON, I., KATES, R.W., WHITE, G.F. The Environment as Hazard. $2^{\circ}$ ed. New York: Guilford Press, 1993.

CASTRO, S. D. A. Riesgos y peligros: uma visión desde la Geografía. Scripta Nova. Revista Eletrónica de Geografía y Ciencias Sociales, n. 60, 2000.

CHARDON, A. C. La percepción del riesgo y los factores socioculturales de vulnerabilidad: caso de ciudad de Manizales, Colombia. Revista Desastres y Sociedad, n. 8, p. 4-34, 1997.

CHIZZOTTI, A. Pesquisa em ciências humanas e sociais. 5ํe ed. São Paulo: Cortez, 2001.

DI GIULIO, G. M.; FERREIRA, L. C. Governança do risco: uma proposta para lidar com riscos ambientais no nível local. Desenvolvimento e Meio Ambiente, v. 28, p. 29-39, 2013.

https://doi.org/10.5380/dma.v28i0.30171

DOUGLAS, M. Risk and Blame: Essays in Cultural Theory. Paperback, ed. London: Routledge, 1994.

DUTRA, A.S.F.; NAVONI, J.A.; AMARAL, V.S. Percepção do Risco Ambiental de uma população exposta a atividade de Mineração no Semiárido Nordestino. Educação Ambiental em Ação, n. 67, 2019.

FERENTZ, L.M.S.; GARCIAS, C.M.; SETIM, L.C.F. Proposta de um indicador de desenvolvimento sustentável com base na qualidade de vida, bem-estar e felicidade: estudo piloto na cidade de Curitiba, Brasil. Análise Social, n. 234, p. 168-192, 2020.

https://doi.org/10.31447/as00032573.2020234.07

IPCC. Intergovernmental Panel on Climate Change: Climate Changes - The physical science basis. Summary of Policymakers, 2013. 33p.

KATES, R. W. Risk assessment of environmental hazard. Chichester: John Wiley, 1978.

JACOBI, P. R. Dilemas socioambientais na gestão metropolitana: do risco à busca da sustentabilidade urbana. Política e Trabalho, Revista de Ciências Sociais, n. 25, p. 115-134, 2006.

LIMA, M.D.V.; RONCAGLIO, C. Degradação socioambiental urbana, políticas públicas e cidadania. Desenvolvimento e Meio Ambiente, v.1, n. 3, p. 53-63, 2001. https://doi.org/10.5380/dma.v3i0.3028

LYNCH, K. A boa forma da cidade. Lisboa: Edições 70, 1999.

MARANDOLA JR., E.; HOGAN, D. J. Natural hazards: o estudo geográfico dos riscos e perigos.

Ambiente \& Sociedade, v. 7, n. 2, p. 95-110, 2004. https://doi.org/10.1590/S1414$\underline{753 \times 2004000200006}$

MENDONÇA, F.A. Resiliência Urbana: Concepções e desafios em face de mudanças climáticas globais. In: FURTADO, F.; PRIORI JUNIOR, L., ALCANTARA, E. (Orgs). Mudanças climáticas e resiliência de cidades. Recife: Pikimagem, 2015. p. 45-60.

MENDONÇA, F. A.; BUFFON, E. A. M.; GOUDARD, G. l'adaptation urbaine au changement climatique global: les inondations à Curitiba et Pinhais (Brésil) In: XXVIlle Coloque de l'Associon Internationale de Climatologie. Liège (Sart-Tilman)/Belgique, 2015.

MENDONÇA, F.A, ROSEGHINI, W.F.F. Eventos climáticos extremos: uma abordagem a partir dos riscos e vulnerabilidades socioambientais. In: SILVA, C.A.; FIALHO, E.S. Concepções e ensaios da Climatologia Geográfica. Dourados: Editora da UFGD, 2012, p. 209-232.

MONTEIRO, C.A.F. Clima e Excepcionalismo: conjecturas sobre o desempenho da atmosfera como fenômeno geográfico. Florianópolis: Editora da UFSC, 1991.

MOSER, S.C. Talk to the city: engaging urbanities on climate change. Environmental Research Letters, v. 1, p.1-10, 2006. https://doi.org/10.1088/1748-9326/1/1/014006

NORDER, L.A.; LOBO, N.S. A percepção dos profissionais de educação sobre os impactos dos agrotóxicos em escolas rurais no Estado do Mato Grosso. Revista Nera, v. 22, n. 46, p. 41-57, 2019. https://doi.org/10.47946/rnera.v0i46.5770

OLIVEIRA, A.A.; BORGES, J.T. Análise da vulnerabilidade populacional aos riscos tecnológicos ambientais na área urbana da cidade de Manaus-AM. Desenvolvimento e Meio Ambiente, v. 49, p. 283-304, 2018. https://doi.org/10.5380/dma.v49i0.59260

$\begin{array}{llllll}\text { Caminhos de Geografia } & \text { Uberlândia-MG } & \text { v. 22, n. } 83 & \text { out./2021 } & \text { p. 01-18 } & \text { Página } 17\end{array}$


PEREIRA, A.R.; ANGELOCCI, L.R.; SENTELHAS, P.C. Agrometeorologia - fundamentos e aplicações práticas. Guaíba: Ed. Agropecuária, 2002. 478p.

POMPILIO, M.J. O homem e as inundações na Bacia do rio Itajaí: uma contribuição aos estudos da geografia do comportamento e da percepção, na linha da percepção ambiental. Tese (Doutorado em Geografia Física) - São Paulo: USP. 1990.

RENN, O. Risk Governance. Coping with Uncertainty in a Complex World. London: Earthscan, 2008.

RIBEIRO, J.; VIEIRA, R.; TÔMIO, D. Análise da percepção do risco de desastres naturais por meio da expressão gráfica de estudantes do Projeto Defesa Civil na Escola, Desenvolvimento e Meio Ambiente, v. 42, p. 202-223, 2017. https://doi.org/10.5380/dma.v42i0.46271

SANTOS, F. M. dos; MARANDOLA JR, E. J. Populações em situação de risco ambiental e vulnerabilidade do lugar em São Sebastião, Litoral de São Paulo. Desenvolvimento e Meio Ambiente, v. 26, p. 103-125, 2012. https://doi.org/10.5380/dma.v26i0.26097

SLOVIC, P. The perception of risk. Londres: Earthscan, 2000.

SOUSA, M. C. de; LIMA, P. V. P. S.; KHAN, A. S. Mecanismos de gestão municipal e a promoção dos direitos humanos. Revista de Administração Pública, v. 49, n. 4, p. 985-1009 2015.

https://doi.org/10.1590/0034-7612135619

SOUZA, L.B.; ZANELA, M.E. Percepção de riscos ambientais: teoria e aplicações. Fortaleza: Edições UFC, 2010.

SULAIMAN, S. N., ALEDO, A. Desastres naturais: convivência com o risco. Estudos Avançados:

São Paulo, v. 30, n. 88, 2016, p. 11-23. https://doi.org/10.1590/s0103-40142016.30880003

SZYMANSKI, H. Entrevista reflexiva: um olhar psicológico sobre a entrevista em pesquisa. In:

SZYMANSKI, H.; ALMEIDA, L. R.; PRANDINI, R. C. A. R. A Entrevista na pesquisa em educação: a prática reflexiva. Brasília: Liber Livro, 2008.

TUAN, Y. Espaço e lugar: a perspectiva da experiência. São Paulo: Difel, 1983.

VESTENA, L., GEFFER, E., ALMEIDA, D.E.F., VESTENA, C.L.B. Percepção Ambiental sobre as causas das inundações, Guarapuava/PR: em busca da cidade resiliente. Revista do Departamento de Geografia - USP, v. 28, p. 280-294, 2014. https://doi.org/10.11606/rdg.v28i0.573

VEYRET, Y. Os Riscos: o homem como agressor e vítima do meio ambiente. São Paulo: Contexto, 2007.

WHITE, G.F. Natural Hazerds (local, national, global). New York: Oxford University Press USA, 1974.

WHYTE, A.V.T. Perception. In: KA TES, R. W.; AUSUBEL, J. H.; BERBERIAN, M. (Ed.). Climate impact assessment: studies of the interaction of climate and society. Chichester: John Wiley, 1985. p. 107-131.

XAVIER, H. Percepção geográfica dos deslizamentos de encostas em áreas de risco no município de Belo Horizonte, MG. 222 f. Tese (Doutorado em Geografia) - Rio Claro: UNESP. 1996.

Recebido em: 28/05/2020

Aceito para publicação em: 11/08/2020 